\title{
Evaluation of Low Heat Unit Corn Hybrids Compared to Barley for Forage Yield and Quality on the Canadian Prairies
}

\author{
Herbert Andrew Lardner ${ }^{1,2}$, Leah Pearce ${ }^{2} \&$ Daalkhaijav Damiran ${ }^{1,2}$ \\ ${ }^{1}$ Department of Animal and Poultry Science, University of Saskatchewan, 51 Campus Drive, Saskatoon, SK S7N \\ 5A8, Canada \\ ${ }^{2}$ Western Beef Development Centre, P.O. 1150, Humboldt, SK S0K 2A0 Saskatchewan, Canada \\ Correspondence: H.A. Lardner, Department of Animal and Poultry Science, University of Saskatchewan, 51 \\ Campus Drive, Saskatoon, SK, S7N 5A8. Canada. Tel: 306-966-2147. E-mail: blardner.wbdc@pami.ca
}

Received: November 28, 2016 Accepted: December 15, $2016 \quad$ Online Published: January 10, 2017

doi:10.5539/sar.v6n1p90 URL: http://dx.doi.org/10.5539/sar.v6n1p90

\begin{abstract}
Corn (Zea mays L.) production is expanding in the prairie region of western Canada. The objectives of this study were to compare three new low heat unit corn hybrids to barley (Hordeum vulgare L.) for forage yield, nutrient profile, and total nutrient production. The study was conducted at 4 sites (Evansburg and Fairview, Alberta; Melfort and Scott, Saskatchewan) with different soil characteristics (Gray Luvisolic, Grey Wooded, Dark Brown, and Black soil zones) over three consecutive years (2012-2014). At each site, annually, 16 plots $(2.4 \times 7.2 \mathrm{~m})$ were randomly assigned to one of four forage crops (corn: Monsanto DKC26-25, Hyland 2D093, Pioneer P7443R; barley: cv. AC Ranger) in a replicated $(n=4)$ trial. Number of cobs per plant was not different $(p=$ 0.23 ) between corn hybrids averaging $1.22 \pm 0.32$ /plant (mean \pm sd). Forage yield among the corn hybrids was negligible $(p>0.05)$, but the corn hybrids exhibited $40 \%$ higher yield $(p<0.05 ;$ avg. $11.3 \pm 3.6 \mathrm{t} / \mathrm{ha}$ on DM basis) compared to barley (avg. $6.7 \pm 1.7$ t/ha). Corn hybrids were lower $(p<0.05)$ in CP content $[7.6 \pm 1.4 \%$ versus (vs.) $12.4 \pm 0.1 \%$ ] than barley. No difference was observed between the 4 forage crops in TDN content $(68.2 \pm$ $2.8 \% \mathrm{DM})$. Study results suggest that new cool-season corn hybrids can produce high quality forage to meet the nutrient requirements of grazing beef cows in mid- and late-stage pregnancy. New corn hybrids may be suitable alternatives for winter grazing strategies since forage harvest costs would be eliminated.
\end{abstract}

Keywords: barley, corn, forage, nutritive value, warm-season crop, growing degree days

\section{Introduction}

Winter feeding costs are a major contributor to the overall cost of production for cow-calf producers (Krause et al., 2013). Traditionally, these costs are due to feeding cows in drylot pens over the winter period, which includes costs for harvesting, handling, and transporting feed and removal of manure (Kelln et al., 2011; Krause et al., 2013). Grazing beef cows on annual stockpiled forages or swath grazing during the winter months are options to potentially reduce the costs of wintering beef cows (Van De Kerckhove et al., 2011; Krause, et al., 2013). Cool season annual forages such as barley (Hordeum vulgare L.) are well suited to western Canadian growing conditions and provide acceptable forage yield and quality (McCartney et al., 2008; Kelln et al., 2011; Kumar et al., 2012). Corn (Zea mays L.) as a winter grazing crop for beef cattle has been more limited to the southern areas of eastern Canada, or southern areas of the prairies. Corn is a warm season annual, usually seeded late with variation in the date of maturity depending on the geographic location and available corn heat units (CHU) (May et al., 2007). However, early seeding of late maturing hybrids of corn has immense potential for use in extensive winter grazing systems (Saskatchewan Ministry of Agriculture [SMA], 2008). Previous grazing trials at Lanigan, Saskatchewan suggested that corn can serve as an excellent winter foraging crop, left either standing or swathed (Lardner, 2002). Standing corn can also serve as an effective windbreak for grazing cattle during winter and snow depth will not limit animal access to the crop as corn stands well above the ground (Baron et al., 2003). The corn grown in the Canadian prairies is different from the corn hybrid varieties grown in warmer climates (Lassiter et al., 1958). The main differences are due to the shorter growing season and lower growing temperatures in the Canadian prairies compared with the areas of warm-season corn production, such as the United States (Lauer et al., 2001; Abeysekara et al., 2013). Many corn hybrids for western Canada require $\geq 2,300$ crop heat units (CHU) to reach the silage harvest stage, with a kernel maturity of $45 \%$ dry matter (DM). 
Recently, with the introduction of low heat unit corn hybrids [i.e., Pioneer P7443R (Pioneer Hi-Bred International Inc., Johnston, IA), Hyland 2D093 (Hyland Seeds, Blenheim, ON, Canada), Monsanto DKC26-25 (Monsanto Creve Coeur, Greater St. Louis, Missouri] suited to western Canadian weather, there is an increased interest in the use of warm season annuals in extensive grazing systems (Lardner et al., 2012; Jose, 2015). In order to establish these hybrids as a forage crop, these must be compared against other commonly used (conventional) forage crops such as whole plant barley. In addition, differences in forage quantity and quality of these newly developed corn hybrids may occur due to growing environment and soil quality. The objectives of this study were to compare new low-heat-unit corn hybrids to forage barley in terms of forage yield and nutrient value in different soil zones on the western Canadian prairies.

\section{Materials and Methods}

\subsection{Site Selection, Pre-Planting Soil Analysis and Experimental Design}

The study was conducted at 4 different sites located in Alberta and Saskatchewan (western Canada) over 3 consecutive years (2012, yr 1; 2013, yr 2; 2014, yr 3). The research sites were established on a Gray Luvisolic soil at Fairview, Alberta, a Grey Wooded soil at Evansburg, Alberta, a Dark Brown soil at Scott, Saskatchewan and a Black soil at Melfort, Saskatchewan. All sites were selected to be typical of areas for expansion of growing whole plant corn for grazing management. Each year, certified seed of 3 corn hybrids, Monsanto DKC 26-25, Pioneer P7443R, Hyland 2D093, and 1 forage barley hybrid, AC Ranger were established at all 4 sites. At each site, 16 plots were randomly assigned to 1 of 4 annual crops ( 3 corn hybrids [DKC26-25; 2D093; P7443R]; 1 barley variety [AC Ranger]) in a replicated $(n=4)$ forage crop production plot trial. Individual plot size was $3.8 \times 14 \mathrm{~m}$ with a $0.5 \mathrm{~m}$ gap between treatment plots and a $3 \mathrm{~m}$ gap between forage replicates. Each year, in order to determine nutrient requirements, prior to seeding, soil samples were collected from 10 random locations at each site from the top $0-15 \mathrm{~cm}$ and analysed by a commercial laboratory for nitrate- $\mathrm{N}$, ammonium-N, phosphorus (P), potassium (K), and sulphur (S). The P7443R, 2D093, and DKC26-25 corn hybrids were rated at 2150, 2000 and 2250 CHU maturity, respectively.

\subsubsection{Fairview Alberta}

The study site was located at the Peace Country Beef and Forage Association Research Farm, Fairview, Alberta, Canada $\left(56^{\circ} 08^{\prime} \mathrm{N} 118^{\circ} 44^{\prime} \mathrm{W}\right)$. The soil type was classified as a Gray Luvisolic soil, loamy argileux (Perkins et al., 1986) and long-term average CHU's were 1800 to 2000 [Alberta Agriculture Food and Rural Development (AAFRD), 2001]. The site history was fallow in summer of 2011, and canola grown in 2010. A soil test was conducted each year prior to seeding for determination of N, P, K and S, followed by harrowing of the site. The soil had a pH of 5.2 and $8.1 \%$ organic matter. Soil N, P, and K levels were maintained as recommended by the Alberta Fertilizer Guide (AAFRD, 2004). Each year, before seeding, corn plots were fertilized with $112 \mathrm{~kg}$ actual $\mathrm{N} / \mathrm{ha}+45 \mathrm{~kg}$ actual $\mathrm{P} / \mathrm{ha}$, while the barley plots received $45 \mathrm{~kg}$ actual N/ha $+26 \mathrm{~kg}$ actual P/ha. The fertilizer was drilled into the plots using a small plot drill. Corn and barley crops were seeded on May 28, May 23, and May 30 in yr 1, yr 2, and yr 3, respectively. Corn was seeded with a 6-row John Deere 7200 corn planter with a row spacing of $75 \mathrm{~cm}$ at a rate of 74100 seeds/ha at a depth of $4 \mathrm{~cm}$, while the barley was seeded at the rate of $112 \mathrm{~kg} / \mathrm{ha}$ using a 7-row plot drill (spaced at $17.5 \mathrm{~cm}$ between rows) at a seeding depth of $4 \mathrm{~cm}$. Each yr, the barley was sprayed with 2-4 D amine at $1.7 \mathrm{~L} / \mathrm{ha}$ at the 4-leaf stage (mid-June), and corn was sprayed with glyphosate [N-(phosphonomethyl) glycine] at $1.7 \mathrm{~L} / \mathrm{ha}$ application rate at the 4-leaf stage (late-June). In addition during yr 2, plots were hand-weeded so that plots were weed-free. When barley reached soft dough stage on August 4, August 1, and July 29 for yr 1, yr 2, and yr 3, respectively, barley plots were harvested for estimation of forage biomass yield. Corn forage yield was determined (see Section 2.2 for details) at kernel half milk line stage on October 4, September 26, and September 29, for yr 1, yr 2, and yr 3, respectively. All forage samples were clipped, weighed and dried for DM determination and laboratory analyses.

\subsubsection{Evansburg Alberta}

Field trials were conducted at the West Central Forage Association Research Farm $\left(53^{\circ} 57^{\prime} \mathrm{N} 115^{\circ} 12^{\prime} \mathrm{W}\right)$, located at Evansburg, Alberta, Canada. Soils were classified as imperfectly drained Gleyed Orthic Gray Wooded soils developed on weakly to moderately calcareous stratified lacustrine material and long-term average CHU's were 1800 to 2000 (AAFRD, 2001). Corn was seeded June 4, June 11, and May 13 in yr 1, yr 2, and yr 3, respectively with a Versatile $2.5 \mathrm{~cm}$ hoe seeder at a row spacing of $75 \mathrm{~cm}$ at 74100 seeds/ha at a depth of $4 \mathrm{~cm}$ and barley was seeded on June 20, June 7, and May 13 in yr 1, yr 2, and yr 3, respectively at a depth of $4 \mathrm{~cm}$ at $108 \mathrm{~kg} / \mathrm{ha}$ and a row spacing of $25 \mathrm{~cm}$. At time of seeding, all plots were side-banded with $113.1 \mathrm{~kg} / \mathrm{ha} \mathrm{N}, 44.8 \mathrm{~kg} / \mathrm{ha} \mathrm{P}_{2} \mathrm{O}_{5}, 33.6$ $\mathrm{kg} / \mathrm{ha} \mathrm{K}_{2} \mathrm{O}$, and $16.8 \mathrm{~kg} / \mathrm{ha}$ sulfur. Corn plots were sprayed each yr with a pre-seeding burn and at 4-leaf stage (early July) with $0.84 \mathrm{~L} / \mathrm{ha}$ glyphosate. Barley plots were sprayed with $2-4 \mathrm{D}$ amine at $0.67 \mathrm{~L} / \mathrm{ha}$ at the 4-leaf 
stage (late June). Corn and barley forage yield was determined (see Section 2.2 for details) on October 16, October 28, and September 10 in yr 1, yr 2, and yr 3, respectively.

\subsubsection{Scott Saskatchewan}

Field trials were conducted at the Agriculture and Agri-Food Canada Research Farm, Scott, Saskatchewan, Canada, located in the Dark Brown Chernozemic soil zone $\left(52^{\circ} 21^{\prime} \mathrm{N} 108^{\circ} 49^{\prime} \mathrm{W}\right)$. Soil type was classified as an Elstow loam (Saskatchewan Soil Survey, 1992). Long-term average CHU's were 2001 to 2100 (SMA, 2010). The site grew canola in 2010 and was left to fallow in the summer of 2011 A soil test was conducted each year prior to seeding for determination of $\mathrm{N}, \mathrm{P}, \mathrm{K}$ and $\mathrm{S}$, followed by harrowing of the site. Corn plots were fertilized with $52 \mathrm{~kg}$ actual N/ha, $22 \mathrm{~kg}$ actual $\mathrm{P}_{2} \mathrm{O}_{5} / \mathrm{ha}, 20 \mathrm{~kg} / \mathrm{ha}$ actual $\mathrm{K}_{2} \mathrm{O}$ broadcast pre-seeding and at seeding with 76 $\mathrm{kg} / \mathrm{ha} \mathrm{N}$ side banded. Then, 6.7, 11.2, 5.6, and $5.6 \mathrm{~kg} / \mathrm{ha}$ actual $\mathrm{N}_{2} \mathrm{P}_{2} \mathrm{O}_{5}, \mathrm{~K}_{2} \mathrm{O}$, and $\mathrm{S}$, respectively was placed adjacent to seed at planting. Each yr, barley plots received $67 \mathrm{~kg}$ actual $\mathrm{N} / \mathrm{ha}$ through side banding at seeding. Corn plots were seeded May 18, May 30, and May 28 in yr 1, yr 2, and yr 3, respectively. Corn was seeded with a Versatile $2.54 \mathrm{~cm}$ hoe seeder at a row spacing of $75 \mathrm{~cm}$ at 74100 kernels/ha at a $4 \mathrm{~cm}$ depth. Barley was seeded on June 22, June 12, and May 28 in yr 1, yr 2, and yr 3, respectively at $108 \mathrm{~kg} / \mathrm{ha}$ and a depth of $4 \mathrm{~cm}$ with a row spacing of $25 \mathrm{~cm}$. All plots received a mid-May pre-seeding burn off with glyphosate at $1 \mathrm{~L} / \mathrm{ha}$. Each yr, corn was sprayed with $0.67 \mathrm{~L} / \mathrm{ha}$ glyphosate at the 4-leaf and 8-leaf stages and barley plots were sprayed with 2-4 D amine at $0.67 \mathrm{~L} / \mathrm{ha}$ at the 4-leaf stage. Corn forage yield was determined (see Section 2.2 for details) at half milk line stage on October 4, September 26, and July 29, in yr 1, yr 2, and yr 3, respectively, while barley plots were harvested at soft dough on August 4, August 1, and July 29 in yr 1, yr 2, and yr 3, respectively.

\subsubsection{Melfort Saskatchewan}

The site was located at the Agriculture and Agri-Food Canada Research Farm, Melfort, Saskatchewan, Canada $\left(52^{\circ} 44^{\prime} \mathrm{N} 104^{\circ} 47^{\prime} \mathrm{W}\right)$. The soil was classified as thick Black Chernozem (Udic Boroll) silty clay soil and long-term average CHU's were 2100 to 2200 (SMA, 2010). In early June, $\mathrm{N}$ fertilizer was broadcasted at $84 \mathrm{~kg}$ N/ha prior to seeding. Corn was seeded on May 15 (yr 1), May 23 (yr 2), and June 9 (yr 3), at 71400 kernels/ha using a Hege plot drill (Hege Equipment Inc., Colwich, KS) at $4 \mathrm{~cm}$ depth with a $75 \mathrm{~cm}$ row spacing, while barley was seeded at $108 \mathrm{~kg} / \mathrm{ha}$ on June 12 (yr 1), July 2 (yr2, and July 3 (yr 3) with a 7-row plot drill (spaced at $17.5 \mathrm{~cm}$ between rows) at $4 \mathrm{~cm}$ depth. Corn plots were sprayed with glyphosate at $1.7 \mathrm{~L} / \mathrm{ha}$ at the 4-leaf stage (June 12, June 24, and July 2 for yr 1, yr 2, and yr 3, respectively), while barley plots were hand weeded each yr eliminating any weeds or volunteer canola. Barley forage yield was determined on August 20, September 4, and August 25 in yr 1, yr 2, and yr 3, respectively. Corn forage yield was determined (see Section 2.2 for details) on September 14, September 20, and October 8 in yr 1, yr 2, and yr 3, respectively.

\subsection{Estimation of Whole Plant Dry Matter Yield and Number of Cobs Per Plant}

Each yr, corn plots were harvested following the first killing frost, with most hybrids at the $2 / 3$ milk line (R5 stage) stage of maturity. Prior to harvesting, the number of cobs per plant was also determined. At each site, corn forage yield was determined by randomly harvesting 3 entire rows $(5.25 \mathrm{~m})$ of corn followed by weighing material to obtain a wet weight. From each corn plot, 3 random corn stalks including cobs were selected as sample (>1 kg) and chopped to $1 \mathrm{~cm}$ in size. Forage yield of barley was determined at the soft dough stage by harvesting full plants above $7 \mathrm{~cm}$ stubble height followed by determining wet weight. A 10 random grab samples $(>1 \mathrm{~kg})$ of swathed forage were taken from each barley plot. All selected samples were placed in a forced air oven at $55^{\circ} \mathrm{C}$ for $72 \mathrm{~h}$ to determine DM percentage and saved for subsequent forage quality analysis. Plot DM yield was determined by multiplying the DM concentration by the plot fresh weight and was expressed in tonne (t)/ha.

\subsection{Forage Quality Analysis}

All forage samples were ground to pass through a 1-mm screen using a Thomas-Wiley Laboratory Mill (Model 4, Thomas Scientific, Swedesboro, NJ, USA). Crude protein (CP) was determined by nitrogen combustion (method 990.03, AOAC, 2000) using a Leco FP-528 Nitrogen Combustion Analyzer (Leco, MI, USA). Neutral detergent fiber (NDF) was determined as described in Van Soest et al. (1991) and acid detergent fiber (ADF) according to method 973.18 (AOAC, 2000). Calcium (Ca) and phosphorus (P) were analyzed using the dry ashing procedure (methods 927.02 and 965.17; AOAC, 2000, respectively). The Ca was determined using an atomic absorption spectrophotometer (Perkin-Elmer, Model 2380, CN, USA), while P concentration was read at $410 \mathrm{~nm}$ on a spectrophotometer (Pharmacia, LKB-Ultraspec ${ }^{\circledR}$ III, Stockholm, Sweden). Total digestible nutrients (TDN; \% $\mathrm{DM}$ ) and metabolizable energy (ME; Mcal/kg DM) were calculated using the grass-legume Penn-State equation based on ADF as described Adams (1995). All data on forage yield and nutritive quality are reported on a DM basis. 


\subsection{Calculation of Nutrient Yield}

Nutrient yield per hectare was calculated by multiplying crop forage yield ( $t / h a)$ by nutrient concentration to allow a comparison of nutrient yield potential for animal feed production among the forage crops.

\subsection{Climate Data}

Monthly average precipitation and temperature (Table 1) were obtained from Environment Canada (www.climate.weatheroffice.ec.gc.ca) for each site. The difference in average temperature between trial years and long-term averages (30 year avg.) was negligible for all four sites (ranged 98.7 to $104.2 \%$ of long-term average). Major difference was in rainfall, with 11 and 15\% above the long-term average observed for April to October at Melfort and Scott, Saskatchewan, respectively. However, trial years were drier (precipitation lower by 35\%) compared to long-term average at Fairview, Alberta. Overall, these data suggested that the current study was conducted in an environment with comparable temperatures and with higher (Melfort and Scott, SK) or lower (Fairview, $\mathrm{AB}$ ) precipitation relative to the long-term average. Total precipitation from April to October (growing season) was 235, 302, 326, and $347 \mathrm{~mm}$ for Fairview, Evansburg, Scott, and Melfort, respectively, averaged over the three trial years. Therefore, soil moisture was assumed to be not limiting at any location.

Table 1. Precipitation and temperature over 3 growing seasons (2012-2014) and long-term average at 4 sites in Canadian prairies*

\begin{tabular}{lrrrrrrrr}
\hline & \multicolumn{2}{c}{ Fairview AB } & \multicolumn{2}{c}{ Evansburg AB } & \multicolumn{2}{c}{ Scott SK } & \multicolumn{2}{c}{ Melfort SK } \\
\hline Month & 3yr-avg. & Avg. $\dagger$ & 3yr-avg. & Avg. & 3yr-avg. & Avg. & 3yr-avg. & Avg. \\
\hline \multicolumn{2}{l}{ Precipitation (mm) } & & & & & & & \\
\hline April & 23.7 & 23.0 & 38.5 & 23.0 & 26.1 & 23.8 & 25.6 & 22.0 \\
May & 33.1 & 36.0 & 49.4 & 36.0 & 41.5 & 35.5 & 32.9 & 47.0 \\
June & 57.5 & 60.0 & 44.9 & 60.0 & 124.6 & 67.3 & 127.4 & 70.0 \\
July & 29.9 & 59.0 & 93.1 & 59.0 & 64.9 & 65.6 & 79.7 & 77.0 \\
August & 25.9 & 45.0 & 35.9 & 45.0 & 46.1 & 43.7 & 45.6 & 33.0 \\
September & 31.9 & 32.0 & 26.5 & 32.0 & 15.5 & 31.8 & 13.0 & 34.0 \\
October & 32.9 & 31.0 & 13.7 & 31.0 & 7.3 & 13.9 & 22.6 & 29.0 \\
\hline Temperature $\left({ }^{\circ} \mathrm{C}\right)$ & & & & & & & & \\
\hline April & 0.9 & 4.1 & 2.6 & 3.2 & 1.0 & 3.3 & -0.8 & 3.1 \\
May & 10.1 & 9.1 & 10.5 & 10.2 & 10.5 & 10.7 & 11.6 & 9.6 \\
June & 13.8 & 13.0 & 14.2 & 14.5 & 14.6 & 15.2 & 14.8 & 14.9 \\
July & 16.6 & 14.9 & 17.3 & 17.3 & 17.5 & 17.2 & 17.8 & 17.3 \\
August & 15.9 & 13.8 & 16.5 & 16.1 & 17.0 & 16.4 & 17.4 & 17.3 \\
September & 11.5 & 9.8 & 12.0 & 10.4 & 12.5 & 10.3 & 13.0 & 11.2 \\
October & 2.9 & 4.0 & 3.8 & 4.6 & 3.4 & 4.3 & 3.0 & 3.5 \\
\hline
\end{tabular}

*Source $=$ Environment Canada (www.climate.weatheroffice.ec.gc.ca); farmzone Canada (www.farmzone.com), The Weather Network (www.theweathernetwork.com).

$\dagger 30$ yr-average

For each experimental site, crop heat units (CHU) were calculated on a daily basis, using the maximum (Tmax) and minimum (Tmin) daily air temperatures, measured from midnight to midnight, in ${ }^{\circ} \mathrm{C}$. The following equation was used to calculate daily CHU: Daily CHU $=(Y \max +\mathrm{Ymin}) / 2$; where $\mathrm{Ymax}=[3.33 \times(\mathrm{Tmax}-10)]$ $\left[0.084 \times(\text { Tmax }-10)^{2}\right]$ (if $Y \max <0$, set $\left.Y \max =0\right)$ and $Y \min =[1.8 \times(\mathrm{Tmin}-4.4)]($ if $Y \min <0$, set $Y \max =0)$. Many corn hybrids for western Canada require $\geq 2300 \mathrm{CHU}$ to reach the silage harvest stage, with a kernel maturity of $45 \%$ DM. In corn cultivation, $\mathrm{CHU}$ accumulation from planting until first killing frost $\left(-2^{\circ} \mathrm{C}\right)$ was not different ( $p=0.69$; data not shown) due to trial site and was 1749, 1850, 1767 and 1894 for Fairview, Evansburg, Scott, and Melfort, respectively (Table 2). In barley cultivation, growing degree days (GDD) are calculated using the following equation: $\mathrm{GDD}=\left[\left(\mathrm{Tmax},{ }^{\circ} \mathrm{C}+\mathrm{Tmin},{ }^{\circ} \mathrm{C}\right) / 2-5\right]$. In the current study, 3 -yr average $\mathrm{CHU}$ was not different $[1219 \pm 87$ (mean \pm sd); $p=0.60]$ among the sites. Days to harvest were 92, 118, 121, and 100 for Evansburg, Fairview, Melfort, and Scott, respectively. 
Table 2. Summary of planting, harvesting date, and crop heat unit (CHU) at four sites in Canadian prairies over the 3 yr study

\begin{tabular}{lccccc}
\hline Year (YR) & Seeding date & Harvesting date & Days to harvest, d & GDD* & CHU $\dagger$ \\
\hline Fairview, $A B$ & & & & & \\
\hline 2012 & May 28 & October 03 & 130 & 1251 & 1997 \\
2013 & May 23 & September 26 & 127 & 1185 & 1954 \\
2014 & May 30 & September 25 & 118 & 1124 & 1749 \\
Average & - & - & $\mathbf{1 2 5}$ & $\mathbf{1 1 8 7}$ & $\mathbf{1 9 0 0}$ \\
\hline Evansburg, $A B$ & & & & & \\
2012 & May 14 & October 07 & 147 & 1304 & 2175 \\
2013 & June 11 & October 28 & 140 & 1132 & 1759 \\
2014 & May 13 & September 10 & 121 & 1168 & 1850 \\
Average & & & $\mathbf{1 3 6}$ & $\mathbf{1 2 0 2}$ & $\mathbf{1 9 2 8}$ \\
\hline Scott, $S K$ & & & & & \\
2012 & May 18 & September 12 & 118 & 1239 & 2056 \\
2013 & May 30 & September 27 & 120 & 1311 & 2131 \\
2014 & May 28 & September 5 & 100 & 1074 & 1767 \\
Average & - & - & $\mathbf{1 1 3}$ & $\mathbf{1 2 0 8}$ & $\mathbf{1 9 8 4}$ \\
\hline Melfort, $S K$ & & & & & \\
2012 & May 15 & September 14 & 123 & 1312 & 2138 \\
2013 & May 23 & September 21 & 121 & 1346 & 2171 \\
2014 & June 9 & October 08 & 121 & 1190 & 1894 \\
Average & - & - & $\mathbf{1 2 2}$ & $\mathbf{1 2 8 3}$ & $\mathbf{2 0 6 8}$ \\
\hline
\end{tabular}

*Data calculated from seeding until harvest; Data calculated from seeding until swathing date; GDD = [(Tmax + Tmin $) / 2-5]$, where Tmax $=$ Maximum daily temperature $\left({ }^{\circ} \mathrm{C}\right), \operatorname{Tmin}=$ Minimum daily temperature $\left({ }^{\circ} \mathrm{C}\right)$.

$\dagger \mathrm{CHU}=\left[1.8(\mathrm{Tmin}-4.4)+3.3(\mathrm{~T} \max -10)-0.084(\mathrm{Tmax}-10)^{2}\right] / 2$.

\subsection{Statistical Analysis}

Due to non-homogeneity of variances (Steel et al., 1997) between site-yrs, and $\mathrm{yr} x$ site, yr x treatment interactions $(p<0.05)$, the experiment was analyzed separately for each site-yr and no attempt was made to explain these interactions.

Numerous significant crop $\times$ site interactions were detected for many of the measured variables and thus data were subsequently analyzed by site. The experimental design for this study was a completely randomized design with subsampling and with a $4 \times 4$ factorial arrangement of treatments. For each location, crop production data (number of cobs per plant, DM, and yield) and nutrient density data (CP, TDN, Ca, P, and ME) and nutrient yield obtainable from each hectare field (CPY, TDNY, CaY, PY, and MEY), CHU, and GDD were analyzed using the Proc Mixed Model procedure of SAS (2003); each plot was considered an experimental unit (in total 192 plots for 3-yr trial) using the Satterthwaite method. The model used for the analysis was: $Y_{i j}=\mu+T_{i}+e_{i j}$; where $Y_{i j}$ was an observation of the dependent variable $\mathrm{ij} ; \mu$ was the population mean for the variable; $\mathrm{T}_{\mathrm{i}}$ was the fixed effect of treatment (crops: either DKC26-25 or Monsanto DKC26-25; 2D093 or Hyland 2D093; P7443R or Pioneer P7443R; AC Ranger); and $\mathrm{e}_{\mathrm{ij}}$ was the random error associated with the observation ij. Means were determined using the least squares means statement of SAS and were separated using Tukey's multi-treatment comparison method (Saxton, 1998). Year was included as a random (block) variable in all analyses. In order to examine the relationship between $\mathrm{CHU}$ and forage dependent variables (yield and cob number per plant), correlation analysis was performed using the CORR procedure of SAS (2003). For all statistical analyses, significance was declared at $p<0.05$.

\section{Results}

\subsection{Fairview Site}

\subsubsection{Forage Nutrient Profile}

Effect of treatment on nutritive value, number of cobs per corn plant, DM, and forage yield at the Fairview site over the 3-yr study is presented in Table 3. All four forage crops were similar $(p>0.05)$ in DM $(32.8 \pm 6.0 \%$; mean $\pm \mathrm{sd})$, TDN $(69.8 \pm 2.0 \% \mathrm{DM}), \mathrm{ME}(2.5 \pm 0.07 \mathrm{Mcal} / \mathrm{kg} \mathrm{DM})$, and $\mathrm{P}(0.24 \pm 0.03 \% \mathrm{DM})$ contents. The three 
corn hybrids were similar with each other $(p>0.05)$ in $\mathrm{CP}, \mathrm{Ca}$, as well as NDF, which was however, lower in $\mathrm{CP}$ $(8.9 \pm 1.5$ vs. $14.3 \pm 2.5 \% \mathrm{DM})$ and in $\mathrm{Ca}(0.29 \pm 0.07$ vs. $0.46 \pm 0.04 \% \mathrm{DM})$, but greater $(p<0.05)$ in NDF (51.4 vs. $4.2 \% \mathrm{DM})$ than barley. When pooled, corn hybrids had higher values for ADF ( 28.6\% DM) compared with the barley $(\sim 25.3 \%)$. The DKC26-25 was greater $(p<0.05)$, but 2D093 and P7443R were similar $(p>0.05)$ to barley in $\mathrm{ADF}$.

Table 3. Forage yield and nutrient profile of corn and barley hybrids at Fairview, Alberta CANADA over 3 yr (2012, 2013, and 2014)

\begin{tabular}{lccccc} 
& & \multicolumn{3}{c}{ Corn } & Barley \\
\cline { 2 - 5 } Item* & DKC26-25 & 2D093 & P7443R & Ranger & SEM $\dagger$ \\
\hline Nutrient Profile & & & & & \\
\hline DM, \% & 32.2 & 30.4 & 32.9 & 35.5 & 0.86 \\
CP, \% DM & $9.3^{\mathrm{b}}$ & $8.6^{\mathrm{b}}$ & $8.8^{\mathrm{b}}$ & $14.3^{\mathrm{a}}$ & 0.52 \\
ADF, \% DM & $29.3^{\mathrm{a}}$ & $29.0^{\mathrm{ab}}$ & $27.5^{\mathrm{ab}}$ & $25.3^{\mathrm{b}}$ & 1.06 \\
NDF, \% DM & $51.9^{\mathrm{a}}$ & $51.9^{\mathrm{a}}$ & $50.4^{\mathrm{a}}$ & $43.2^{\mathrm{b}}$ & 1.39 \\
TDN, \% DM & 68.8 & 70.1 & 70.5 & 69.8 & 0.56 \\
ME, Mcal/kg & 2.49 & 2.53 & 2.55 & 2.52 & 0.021 \\
Ca, \% DM & $0.30^{\mathrm{b}}$ & $0.28^{\mathrm{b}}$ & $0.29^{\mathrm{b}}$ & $0.46^{\mathrm{a}}$ & 0.018 \\
P, \% DM & 0.24 & 0.24 & 0.23 & 0.24 & 0.007 \\
\hline Yield & & & & & \\
\hline Cobs/plant & 1.2 & 1.3 & 1.2 & - & 0.04 \\
Forage Yield t/ha & $10.3^{\mathrm{ab}}$ & $9.4^{\mathrm{b}}$ & $12.0^{\mathrm{a}}$ & $6.8^{\mathrm{c}}$ & 0.40 \\
CPY, t/ha & $0.93^{\mathrm{ab}}$ & $0.81^{\mathrm{b}}$ & $1.04^{\mathrm{a}}$ & $0.97^{\mathrm{ab}}$ & 0.030 \\
TDNY, t/ha & $7.09^{\mathrm{b}}$ & $6.58^{\mathrm{b}}$ & $8.40^{\mathrm{a}}$ & $4.74^{\mathrm{c}}$ & 0.279 \\
CaY, t/ha & 0.030 & 0.027 & 0.035 & 0.031 & 0.002 \\
PY, t/ha & $0.025^{\mathrm{a}}$ & $0.023^{\mathrm{a}}$ & $0.027^{\mathrm{a}}$ & $0.016^{\mathrm{b}}$ & 0.001 \\
MEY, Mcal/ha & $25624^{\mathrm{b}}$ & $23752^{\mathrm{b}}$ & $30363^{\mathrm{a}}$ & $17140^{\mathrm{c}}$ & 1010.2 \\
\hline
\end{tabular}

*Means within a row with different superscripts differ $(p<0.05)$.

$\dagger$ SEM, Standard error of mean.

\subsubsection{Forage and Nutrient Yield}

Corn hybrids did not differ $(p>0.05)$ in number of cobs per plant, averaging $1.2 \pm 0.25$. Corn hybrids had higher forage yield (from 38 to $76 \%$ greater; $p<0.05$ ) than barley. Differences $(p<0.01)$ were also detected in the forage yield among corn hybrids: 2D093 was lower $(p<0.05)$, while DKC26-25 was similar $(p>0.05)$ to P7443R. There were no differences among crop hybrids for forage derived CaY $(\mathrm{kg} / \mathrm{ha})(p>0.05)$. As expected based on the observed Forage Yield results, all three corn hybrids were 39 to $77 \%$ greater $(p<0.05)$ than barley in TDNY and consequently, 38 to 77\% greater than barley in MEY. The DKC26-25 and 2D093 were similar with each other $(p>0.05)$, but were 19\% lower than P7443R in TDNY and consequently, 19\% lower in MEY.

\subsection{Evansburg Site}

\subsubsection{Forage Nutrient Profile}

Effect of corn hybrids on forage nutrient profile, number of cobs per plant, DM, and forage yield at the Evansburg site over the study years is presented in Table 4 . All three corn hybrids had similar CP (7.6 $\pm 1.4 \% ; p>$ $0.05)$ content, but that was lower $(12.4 \pm 0.09 \% ; p<0.05)$ than CP of the barley. Barley exhibited $17 \%$ lower $\mathrm{ADF}$ and $22 \%$ lower NDF concentrations than corn resulting in $4 \%$ higher TDN and ME for barley. Barley exhibited 46\% lower $\mathrm{Ca}$ concentration and $16 \%$ lower $\mathrm{P}$ concentration than corn. There were nutrient differences among corn hybrids at Evansburg, Alberta. Hyland 2D093 exhibited $29 \%$ lower ADF, 13\% lower NDF, 43\% lower $\mathrm{Ca}$ and 17\% lower P concentrations than DKC26-25 and P7443R hybrids. 
Table 4. Forage yield and nutrient profile of corn and barley hybrids at Evansburg, Alberta CANADA over 3 yr (2012, 2013, and 2014)

\begin{tabular}{lccccc}
\hline & \multicolumn{3}{c}{ Corn } & Barley & \\
\cline { 2 - 5 } Item* & DKC26-25 & 2 D093 & P7443R & Ranger & SEM $\dagger$ \\
\hline Nutrient Profile & & & & \\
\hline DM, \% & 31.8 & 31.2 & 33.2 & 33.7 & 1.66 \\
CP, \% DM & $8.0^{\mathrm{b}}$ & $7.2^{\mathrm{b}}$ & $7.6^{\mathrm{b}}$ & $12.4^{\mathrm{a}}$ & 0.35 \\
ADF, \% DM & $30.7^{\mathrm{a}}$ & $21.7^{\mathrm{b}}$ & $30.8^{\mathrm{a}}$ & $23.1^{\mathrm{b}}$ & 1.79 \\
NDF, \% DM & $54.2^{\mathrm{a}}$ & $47.4^{\mathrm{b}}$ & $55.0^{\mathrm{a}}$ & $40.7^{\mathrm{c}}$ & 1.73 \\
TDN, \% DM & $66.7^{\mathrm{b}}$ & $67.0^{\mathrm{ab}}$ & $68.5^{\mathrm{ab}}$ & $70.0^{\mathrm{a}}$ & 0.85 \\
ME, Mcal/kg & $2.41^{\mathrm{b}}$ & $2.42^{\mathrm{ab}}$ & $2.47^{\mathrm{ab}}$ & $2.53^{\mathrm{a}}$ & 0.030 \\
Ca, \% DM & $0.33^{\mathrm{ab}}$ & $0.20^{\mathrm{bc}}$ & $0.36^{\mathrm{a}}$ & $0.16^{\mathrm{c}}$ & 0.041 \\
P, \% DM & $0.24^{\mathrm{a}}$ & $0.20^{\mathrm{b}}$ & $0.24^{\mathrm{a}}$ & $0.19^{\mathrm{b}}$ & 0.006 \\
\hline Yield & & & & & \\
\hline Cobs/plant & 0.9 & 1.0 & 1.0 & - & 0.06 \\
Forage Yield t/ha & $13.0^{\mathrm{a}}$ & $10.9^{\mathrm{a}}$ & $11.9^{\mathrm{a}}$ & $6.3^{\mathrm{b}}$ & 1.13 \\
CPY, t/ha & 1.01 & 0.82 & 0.89 & 0.78 & 0.049 \\
TDNY, t/ha & $8.68^{\mathrm{a}}$ & $7.17^{\mathrm{ab}}$ & $7.93^{\mathrm{a}}$ & $4.44^{\mathrm{b}}$ & 0.737 \\
CaY, t/ha & $0.045^{\mathrm{a}}$ & $0.024^{\mathrm{ab}}$ & $0.051^{\mathrm{a}}$ & $0.011^{\mathrm{b}}$ & 0.004 \\
PY, t/ha & $0.030^{\mathrm{a}}$ & $0.022^{\mathrm{b}}$ & $0.027^{\mathrm{ab}}$ & $0.012^{\mathrm{c}}$ & 0.001 \\
MEY, Mcal/ha & $31374^{\mathrm{a}}$ & $25956^{\mathrm{ab}}$ & $28657^{\mathrm{a}}$ & $16052^{\mathrm{b}}$ & 2663 \\
\hline
\end{tabular}

*Means within a row with different superscripts differ $(p<0.05)$.

$\dagger$ SEM, Standard error of mean.

\subsubsection{Forage and Nutrient Yield}

Corn hybrids did not differ $(p>0.05)$ in number of cobs $(0.97 \pm 0.33 /$ plant $)$ and forage DM content $(32.5 \pm 0.56)$. Barley forage yield was $47 \%$ lower than corn yield at Evansburg, Alberta. No differences $(p>0.05)$ were detected between all crops in forage derived CPY (avg. $8.7 \pm 0.27 \mathrm{t} / \mathrm{ha}$ ) per hectare. However, barley TDNY, CaY, PY and MEY were lower than those of corn. Forage yield difference between corn and barley had greater impact on forage nutrient yield parameters than nutrient concentration differences. Monsanto DKC26-25 was lower ( $p<$ 0.05), although 2D093 and P7443R were similar $(p>0.05)$ to barley in TDNY and in MEY.

\subsection{Scott Site}

\subsubsection{Forage Nutrient Profile}

Effect of hybrids on number of cobs per corn plant, forage nutrient profile, and yield at the Scott site over the 3 -yr study is presented in Table 5. Corn hybrids did not differ $(p>0.05)$ in number of cobs, averaging $1.3 \pm 0.25$ cobs per plant. All 3 corns had similar forage yield $(p>0.05 ; 10.0 \pm 2.73 \mathrm{t} / \mathrm{ha})$, that was, nevertheless, higher $(6.9 \pm 1.3 \mathrm{t} / \mathrm{ha} ; p<0.05)$ than that of barley. However, all four forage crops were similar $(p<0.05)$ in DM content $(28.7 \pm 7.7 \%)$ at the time of harvesting. Corn vs. All 3 corn hybrids were lower $(p<0.05)$ than barley in $\mathrm{CP}$ and Ca content. Pioneer P7443R was similar $(p>0.05)$ with both DKC26-25 and 2D093 in CP, ADF, NDF, TDN, as well as ME content. However, compared to 2D093, DKC26-25 was greater $(p<0.05)$ in CP, TDN, and ME, but it was lower $(p<0.05)$ in ADF and NDF. All 3 corns had similar P content $(p>0.05)$ with barley. 
Table 5. Forage yield and nutrient profile of corn and barley hybrids at Scott, Saskatchewan CANADA over 3 yr $(2012,2013$, and 2014)*

\begin{tabular}{lccccc}
\hline & \multicolumn{3}{c}{ Corn } & Barley & \\
\cline { 2 - 5 } Item* & DKC26-25 & $2 \mathrm{D} 093$ & P7443R & Ranger & SEM $\dagger$ \\
\hline Nutrient Profile & & & & & \\
\hline DM, \% & 27.5 & 27.0 & 28.5 & 32.0 & 1.12 \\
CP, \% DM & $9.1^{\mathrm{b}}$ & $7.8^{\mathrm{c}}$ & $8.0^{\mathrm{bc}}$ & $10.3^{\mathrm{a}}$ & 0.32 \\
ADF, \% DM & $26.5^{\mathrm{b}}$ & $33.1^{\mathrm{a}}$ & $30.5^{\mathrm{ab}}$ & $28.4^{\mathrm{b}}$ & 1.12 \\
NDF, \% DM & $49.4^{\mathrm{b}}$ & $55.8^{\mathrm{a}}$ & $52.4^{\mathrm{ab}}$ & $49.0^{\mathrm{b}}$ & 0.97 \\
TDN, \% DM & $69.8^{\mathrm{a}}$ & $66.7^{\mathrm{b}}$ & $67.6^{\mathrm{ab}}$ & $66.3^{\mathrm{b}}$ & 0.79 \\
ME, Mcal/kg & $2.52^{\mathrm{a}}$ & $2.41^{\mathrm{b}}$ & $2.44^{\mathrm{ab}}$ & $2.40^{\mathrm{b}}$ & 0.028 \\
Ca, \% DM & $0.25^{\mathrm{b}}$ & $0.21^{\mathrm{bc}}$ & $0.19^{\mathrm{c}}$ & $0.31^{\mathrm{a}}$ & 0.016 \\
P, \% DM & $0.28^{\mathrm{a}}$ & $0.20^{\mathrm{b}}$ & $0.21^{\mathrm{b}}$ & $0.24^{\mathrm{ab}}$ & 0.018 \\
\hline Yield & & & & & \\
\hline Cobs/plant & 1.2 & 1.3 & 1.3 & - & 0.04 \\
Forage Yield, t/ha & $9.0^{\mathrm{a}}$ & $10.7^{\mathrm{a}}$ & $10.2^{\mathrm{a}}$ & $6.9^{\mathrm{b}}$ & 0.41 \\
CPY, t/ha & 0.82 & 0.84 & 0.81 & 0.72 & 0.033 \\
TDNY, t/ha & $6.28^{\mathrm{a}}$ & $7.09^{\mathrm{a}}$ & $6.89^{\mathrm{a}}$ & $4.62^{\mathrm{b}}$ & 0.268 \\
CaY, t/ha & 0.023 & 0.023 & 0.019 & 0.021 & 0.001 \\
PY, t/ha & $0.026^{\mathrm{a}}$ & $0.022^{\mathrm{ab}}$ & $0.021^{\mathrm{ab}}$ & $0.016^{\mathrm{b}}$ & 0.001 \\
MEY, Mcal/ha & $22707^{\mathrm{a}}$ & $25628^{\mathrm{a}}$ & $24923^{\mathrm{a}}$ & $16698^{\mathrm{b}}$ & 969.6 \\
\hline
\end{tabular}

*Means within a row with different superscripts differ $(p<0.05)$.

$\dagger$ †EM, Standard error of mean.

\subsubsection{Forage and Nutrient Yield}

Forage yield of barley was $31 \%$ lower than corn at Scott, Saskatchewan. The average values of all four crops were similar for CPY $(8.8 \pm 1.5 \mathrm{t} / \mathrm{ha})$ and CaY $(0.02 \pm 0.01 \mathrm{t} / \mathrm{ha})$. All 3 corns were similar $(p>0.05)$ with each other, but they were greater $(p<0.05)$ than barley in TDNY $(6.8 \pm 1.75$ vs. $4.6 \pm 0.94$ t/ha $)$ and MEY $(24419 \pm$ 6357 vs. $16697 \pm 3399 \mathrm{Mcal} / \mathrm{ha}$ ). Forage yield differences were more important when determining nutrient yield differences than crop nutrient concentration at Scott, Saskatchewan.

\subsection{Melfort Site}

\subsubsection{Forage Nutrient Profile}

All 3 corn hybrids had similar DM concentration $(p>0.05)$ with each other, but greater $(p<0.05)$ than barley DM (32.1 \pm 4.1 vs. $24.8 \pm 4.1 \%)$ and TDN $(68.5 \pm 2.1$ vs. $64.5 \pm 2.1 \%)$ (Table 6$)$. The corn hybrids were lower $(p<0.05)$ than barley in $\mathrm{CP}(7.2 \pm 1.2$ vs. $12.6 \pm 2.3 \%), \mathrm{Ca}(0.21 \pm 0.05$ vs. $0.43 \pm 0.16 \%)$, as well as in $\mathrm{P}$ content $(0.20 \pm 0.02$ vs. $0.26 \pm 0.07 \%)$. However, barley exhibited $5 \%$ lower ME concentration than corn. 
Table 6. Forage yield and nutrient profile of corn and barley hybrids at Melfort, Saskatchewan CANADA over $3 \mathrm{yr}$ (2012, 2013, and 2014)

\begin{tabular}{lccccc}
\hline & \multicolumn{3}{c}{ Corn } & Barley & \\
\cline { 2 - 5 } Item* & DKC26-25 & 2D093 & P7443R & Ranger & SEM $\dagger$ \\
\hline Nutrient Profile & & & & & \\
\hline DM, \% & $32.5^{\mathrm{a}}$ & $30.8^{\mathrm{a}}$ & $33.2^{\mathrm{a}}$ & $24.8^{\mathrm{b}}$ & 0.78 \\
CP, \% DM & $7.3^{\mathrm{b}}$ & $7.6^{\mathrm{b}}$ & $6.8^{\mathrm{b}}$ & $12.6^{\mathrm{a}}$ & 0.44 \\
ADF, \% DM & $29.0^{\mathrm{b}}$ & $33.0^{\mathrm{a}}$ & $32.6^{\mathrm{a}}$ & $33.4^{\mathrm{a}}$ & 0.79 \\
NDF, \% DM & $50.7^{\mathrm{b}}$ & $55.8^{\mathrm{a}}$ & $54.2^{\mathrm{ab}}$ & $54.1^{\mathrm{b}}$ & 1.25 \\
TDN, \% DM & $69.1^{\mathrm{a}}$ & $67.2^{\mathrm{a}}$ & $69.0^{\mathrm{a}}$ & $64.5^{\mathrm{b}}$ & 0.52 \\
ME, Mcal/kg & $2.49^{\mathrm{a}}$ & $2.39^{\mathrm{b}}$ & $2.51^{\mathrm{a}}$ & $2.33^{\mathrm{b}}$ & 0.017 \\
Ca, \% DM & $0.21^{\mathrm{b}}$ & $0.24^{\mathrm{b}}$ & $0.18^{\mathrm{b}}$ & $0.44^{\mathrm{a}}$ & 0.026 \\
P, \% DM & $0.20^{\mathrm{b}}$ & $0.20^{\mathrm{b}}$ & $0.20^{\mathrm{b}}$ & $0.26^{\mathrm{a}}$ & 0.011 \\
\hline Yield & & & & & \\
\hline Cobs/plant & 1.4 & 1.5 & 1.5 & - & 0.04 \\
Forage Yield t/ha & $13.2^{\mathrm{a}}$ & $12.0^{\mathrm{a}}$ & $12.7^{\mathrm{a}}$ & $6.7^{\mathrm{b}}$ & 0.64 \\
CPY, t/ha & 0.94 & 0.89 & 0.85 & 0.84 & 0.036 \\
TDNY, t/ha & $9.03^{\mathrm{a}}$ & $8.07^{\mathrm{a}}$ & $8.74^{\mathrm{a}}$ & $4.31^{\mathrm{b}}$ & 0.437 \\
CaY, t/ha & 0.026 & 0.027 & 0.022 & 0.029 & 0.001 \\
PY, t/ha & $0.026^{\mathrm{a}}$ & $0.024^{\mathrm{a}}$ & $0.025^{\mathrm{a}}$ & $0.017^{\mathrm{b}}$ & 0.001 \\
MEY, Mcal/ha & $32628^{\mathrm{a}}$ & $28874^{\mathrm{a}}$ & $31875^{\mathrm{a}}$ & $15570^{\mathrm{b}}$ & 1577.7 \\
\hline
\end{tabular}

*Means within a row with different superscripts differ $(p<0.05)$.

$\dagger$ SEM, Standard error of mean.

\subsubsection{Forage and Nutrient Yield}

Corn hybrids did not differ $(p>0.05$ ) in number of cobs, averaging $1.4 \pm 0.27$ cobs per plant (Table 6). In the same fashion with the other 3 sites, all 3 corn hybrids had similar forage yield (12.6 $\pm 4.12 \mathrm{t} / \mathrm{ha} ; p>0.05)$, which was $47 \%$ higher $(p<0.05)$ than barley $(6.70 \pm 1.1 \mathrm{t} / \mathrm{ha})$. No variation in forage derived CPY (avg. $8.6 \pm 2.8 \mathrm{t} / \mathrm{ha})$ and $\mathrm{CaY}(0.27 \pm 0.13 \mathrm{t} / \mathrm{ha})$ occurred among the four crops. A hybrid effect on the CPY or CaY was not found $(p>$ $0.05)$ between the new corn hybrids. Corn was greater $(p<0.05)$ than barley in TDNY $(8.6 \pm 2.7$ vs. $4.3 \pm 0.68$ $\mathrm{t} / \mathrm{ha})$ and MEY (31125 \pm 9813 vs. $15570 \pm 2465 \mathrm{Mcal} / \mathrm{ha})$ and PY $(0.025 \pm 0.008$ vs. $0.017 \pm 0.017 \mathrm{t} / \mathrm{ha})$. In contrast to the other sites, the higher barley CP is compensated by the higher Forage Yield of corn at Melfort so that CPY was not significantly $(p>0.05)$ different. For the other calculated forage nutrients however, Forage Yield differences contributed to significantly higher TDNY, CaY, PY and MEY for corn compared to barley at Melfort, Saskatchewan.

\subsection{The Relationship between CHU and Forage Yield and Nutrient Profile}

Summarizing all four sites, corn hybrids had good cob development by the end of the growing season over the trial years. When sites were compared (data not shown), Melfort site $(24.8 \%)$ was similar $(p>0.05)$ with Scott (32.0\%), and Evansburg (33.7\%), but was lower $(p<0.05)$ than Fairview $(35.5 \%)$ site on barley DM content by the time of harvesting. Whereas, DM content at harvesting was not different $(p>0.05)$ across the corn hybrids as well as across the trial sites and averaged $30.9 \pm 6.3 \%$ (mean $\pm \mathrm{sd}$ ). When all 4 trial sites were pooled (data not shown), forage yield did not vary $(p>0.05)$ among the 3 corn hybrids. However, on average all corn hybrids had approximately $40 \%$ higher forage yield (avg. $11.3 \pm 3.6$ t/ha) than the AC Ranger barley (avg. $6.7 \pm 1.7 \mathrm{t} / \mathrm{ha}$ ). Summarizing over all four sites, the number of cobs per corn plant had a moderate $(r=0.57, p<0.01)$ correlation, but corn forage yield had a weak correlation $(r=0.31, p=0.06)$ with CHU's, the latter suggesting that low CHU's access leads to a relatively low number of cobs per plant and a minor effect on forage yield. However, corn TDNY and CPY had a moderate positive $(r=0.51, p<0.01)$ and a weak positive correlation $(r=$ $0.34, p<0.04)$ with CHU, respectively. The relationships between CHU and TDNY, and between CHU and CPY were a moderately positive $(r=0.51, p<0.01)$ and a weakly positive $(r=0.34, p<0.04)$, respectively.

\section{Discussion}

Forage yield and nutrient profile are influenced by soil nutrients, plant species, genotype within species, stage of harvest, weather and other environmental conditions (Baron et al., 2012). Specially, successful growth of corn 
depends on the availability of $\mathrm{CHU}$, and corn is considered more suitable to areas receiving a minimum of 2000 to 2100 CHU's (McCartney et al., 2009). On average, CHU's in the current trial were closer with the McCartney et al. (2009) bench mark. Comparable forage yield and nutritive value among corn hybrids and barley at different trial sites could be explained in part by the similar accumulated CHU and GDD across sites during the study years (Table 2). Additionally, plant-available soil nutrients probably were adequate at all 4 sites since soil N, P, and $\mathrm{K}$ were maintained at the levels recommended despite each site representing different soil associations. These observations may help explain the apparent lack of difference that was found among the corn hybrids at these trial sites.

The DM content of corn forage has previously been reported as $32 \%$ to $40 \%$ (Bal et al., 2000; Jurjanz \& Monteils, 2005), a value comparable with the current study findings. Forage yield of barley was in agreement with previous (Aasen et al., 2004; Baron et al., 2012) studies (i.e., 4.2-13.6 t/ha) conducted in Alberta, Canada. Corn forage yield shown in the current study fell within the range of that observed previously in the Canadian prairies (Baron et al., 2006; Baron et al., 2014; Lardner et al., 2012; 8.3-15.9 t/ha).

The NRC (2000) model predicts that a dry beef cow in early to mid-gestation requires 7 to $8 \%$ of CP in the diet for maintenance which increases to 11 to $13 \% \mathrm{CP}$ in young (first parity) growing or lactating cows. Protein content was higher for barley (10.3 to $14.3 \% \mathrm{CP}$ ) than the 3 corn hybrids $(6.8$ to $9.3 \% \mathrm{CP})$. The latter $\mathrm{CP}$ values were in agreement with those of previous work (Baron et al., 2003; Abeysekara et al., 2013) for corn forage. Taking into consideration the protein requirements of beef cattle, in the current study, only AC Ranger barley had sufficient amounts of $\mathrm{CP}$ required by gestating and lactating cows. The 3 corn hybrids were only adequate in the $\mathrm{CP}$ for cows in the mid-gestation stage. Therefore, cows in the late pregnancy stage grazing these corn hybrids (regardless of grown site and of fertility sources) would consequently need some form of protein supplementation (Van De Kerckhove et al., 2011; Jose, 2015; Damiran et al., 2016), or good legume hay (Krause et al., 2013) with high CP content. Nutrient values for low CHU region corn plants (NDF 49, CP 7.1, ADF 28.3, and TDN 67.3\% of DM, ME 2.2 Mcal/kg DM) have been reported previously (Abeysekara et al., 2013) and are in close agreement with our current results.

Energy is probably the most important nutritional consideration in beef cattle production in cold climates. Findings of the present study were in agreement with published values for regular corn forage (TDN $=68.8 \%$; NRC, 2001) Using TDN as the energy source for beef cow, the rule of thumb is 55-60-65 (\%, DM) (Yurchak \& Okine, 2004). This rule says that for a mature beef cow to maintain her body condition score through the winter, the ration must have a TDN energy reading of 55\% in mid pregnancy, $60 \%$ in late pregnancy and 65\% after calving (Yurchak \& Okine, 2004). Therefore, even accounting for weathering effects on plant material for winter grazing (Baron et al., 2003), the result of the current study suggested that all three new corn hybrids had adequate energy needed by dry gestating cows, mid pregnancy cows, as well as late pregnancy cows at all sites. This further confirms that similar with barley, corn is a high energy feed that will normally match the nutritional needs of a dry cow in mid and late pregnancy and after calving. Likewise, a recent Saskatchewan winter field study (Jose, 2015) also suggests that the corn grazing cows were more efficient compared to swathed barley or bale grazing cows, in converting each unit of feed DM to net energy for maintenance and production.

Animal mineral requirements can also vary with the stage and level of production (NRC, 2000). Forage mineral content can be affected due to changes in soil, season and stage of maturity (Kappel et al., 1985). All crops tested in the current study had sufficient amounts of Ca needed for dry gestating cows. None of the crops was however adequate to meet the $0.58 \%$ Ca required by lactating cows (NRC, 2000). Only DKC26-25 and P7443R corn hybrids at Evansburg, Alberta were short of meeting the $0.31 \%$ Ca requirements of growing and finishing beef cattle. Forage P content was between 0.19 and $0.28 \%$ for corn hybrids and AC Ranger barley. These values were within the ranges suggested for growing and finishing beef cattle $(0.21 \% \mathrm{P})$ and dry gestating cows $(0.16 \% \mathrm{P})$ (NRC, 2000). But for lactating cows, which require $0.26 \% \mathrm{P}$ (NRC, 2000), the crops fell short in meeting their $\mathrm{P}$ requirements. This, therefore, indicates that for cows in the late pregnancy stage, some form of mineral supplementation to address the short fall of both forage $\mathrm{Ca}$ and $\mathrm{P}$ contents is needed. In addition, based on the nutrient composition of these new corn hybrids, fresh forage (green chop) would have adequate levels of NDF, ADF, and protein (Weiss et al., 1992; Taylor \& Allen, 2005) for ensiling.

Sustainable management of beef cattle involves balancing the nutrient needs of the animal with the nutritional opportunities of the forage resource. For example, it may be possible to reduce the daily feed cost of swath grazing below that of swathed barley forage by using crop species with potential for higher forage yield and quality, assuming similar costs of production (Baron et al., 2014). As stated in previous section (Section 3), on average, each corn field produced a relatively similar amount of CPY ( 0.89 vs. $0.86 \mathrm{t} / \mathrm{ha})$, but were approximately $65 \%$ greater for TDNY ( 7.7 vs. $4.7 \mathrm{t} / \mathrm{ha}$ ) than what the barley field produced, indicating greater carrying capacities 
for wintering beef cow grazing as this suggests a substantial savings in feed energy costs (Kelln et al., 2011). Thus, the new corn hybrids evaluated in the current study, would fit very well where higher yield from a limited land base is desirable.

\section{Conclusions \& Implications}

Study results confirmed that the new low heat unit corn hybrids had higher biomass and lower CP content than barley across Canadian prairie environments. Very little differences were observed in the yield and nutrient profile among the new corn forage hybrids. The Monsanto DKC 26-25, Pioneer P7443R, and Hyland 2D093, all produced good forage yield and were of suitable quality to meet nutrient requirements of grazing beef cows in the mid and late pregnancy stages. In addition, grazing these corn hybrids whole plant may fit very well where winter grazing is practiced since forage harvest costs would be eliminated. Overall, as the present study demonstrated, new bred low heat unit forage corn is comparable to conventional barley forage in major nutrients content (excluding CP) and availability to animals in major soil zones of Canadian prairies. A long term field grazing research program (with multiple years) needs to be conducted to make a more definitive conclusion.

\section{Acknowledgments}

The present study was supported by the Alberta Livestock and Meat Agency, Saskatchewan Agriculture Development Fund, Hyland Seeds, Monsanto Canada, DuPont Pioneer, West Central Forage Association, Peace Country Beef \& Forage Association, Northeast Agricultural Research Foundation, Western Applied Research Corporation, and Western Beef Development Centre. The authors acknowledge the technical assistance of Dr Paul Jefferson and Enkhjargal Darambazar (University of Saskatchewan).

\section{References}

Aasen, A., Baron, V. S., Clayton, G. W., Dick, A. C., \& McCartney, D. H. (2004). Swath grazing potential of spring cereals, field pea and mixtures with other species. Canadian Journal of Plant Science, 84, 1051-1058. http://dx.doi.org/10.4141/P03-143

Abeysekara, S., Christensen, D. A., Niu, Z., Theodoridou, K., \& Yu, P. (2013). Molecular structure, chemical and nutrient profiles, and metabolic characteristics of the proteins and energy in new cool-season corn varieties harvested as fresh forage for dairy cattle. Journal of Dairy Science, 96, 6631-6643. https://doi.org/10.3168/jds.2013-6841

Adams, R. S. (1995). Dairy nutrition. In: C. Walker (Ed.), Dairy Reference Manual. (pp. 108-109). Northeast Regional. Agricultural Engineering Service, NY: Ithaca.

Alberta Agriculture Food and Rural Development [AAFRD]. (2004). Alberta fertilizer guide. Government of Alberta. Accessed April 2016.

http://www1.agric.gov.ab.ca/\$department/deptdocs.nsf/all/agdex3894/\$file/541-1.pdf?OpenElement.

Alberta Agriculture Food and Rural Development [AAFRD]. (2001). Annual total corn heats units: 1971-2000. http://www1.agric.gov.ab.ca/\$department/deptdocs.nsf/all/sag6442/\$FILE/onl_s_9_twp_annual_normals_1 9712000.gif. Accessed 18 April 2016.

AOAC (Association of Official Analytical Chemists). (2000). Official methods of analysis (17th ed.). AOAC International, Arlington, VA. USA.

Bal, M. A., Shaver, R. D., Shinners, K. J., Coors, J. G., Lauer, J. G., Straub, R. J., \& Koegel, R. G. (2000). Stage of maturity, processing, and hybrid effects on ruminal in situ disappearance of whole-plant corn silage. Animal Feed Science and Technology, 86, 83-94. https://doi.org/10.1016/S0377-8401(00)00163-2

Baron, V. S., Aasen, A., Oba, M., Dick, A. C., Salmon, D. F., Basarab, J. A., \& Stevenson, C. F. (2012). Swath-grazing potential for small-grain species with a delayed planting date. Agronomy Journal, 104, 393-404. https://doi:10.2134/agronj2011.0234

Baron, V. S., Dick, A. C., McCartney, D., Basarab, J. A., \& Okine, E. K. (2006). Carrying capacity, utilization and weathering of swathed whole plant barley. Agronomy Journal, 98, 714-721. http://dx.doi.org/10.2134/agronj2005.0171

Baron, V. S., Doce, R. R., Basarab, J., \& Dick, C. (2014). Swath-grazing triticale and corn compared to barley and a traditional winter feeding method in central Alberta. Canadian Journal of Plant Science, 94, 1125-1137. https://doi.org/10.4141/cjps2013-412

Baron, V. S., Najda, H. G., McCartney, D. H., Bjorge, M., \& Lastiwka, G. W. (2003). Winter weathering effects on corn grown for grazing in a short-season area. Canadian Journal of Plant Science, 83, 333-341. 
https://doi.org/10.4141/P01-202

Damiran, D., Lardner, H. A., Larson, K., \& McKinnon, J. J. (2016). Effects of supplementing spring-calving beef cows grazing barley crop residue with canola meal and wheat-based dry distillers' grains with solubles on performance, reproductive efficiency, and system cost. Professional Animal Scientist, 32, 400-410. https://doi.org/10.15232/pas.2015-01479

Jose, D. (2015). Evaluation of winter feeding systems for crop yield and agronomy, beef cow performance, metabolism and economics. (Unpublished MSc. Thesis). University of Saskatchewan, Saskatchewan, Saskatoon, Canada.

Jurjanz, S., \& Monteils, V. (2005). Ruminal degradability of corn forages depending on the processing method employed. Animal Resources, 54, 3-15. https://doi.org/10.1051/animres:2004041

Kappel, L. C., Morgan, E. B., Kilgore, L., Ingraham, R. H., \& Babcock. D. K. (1985). Seasonal changes of mineral content of southern forages. Journal of Dairy Science, 68, 1822-1827. https://doi.org/10.3168/jds.S0022-0302(85)81033-X

Kelln, B. M., Lardner, H. A., McKinnon, J. J., Campbell, J. R., Larson, K. \& Damiran, D. (2011). Effect of winter feeding system on beef cow performance, reproductive efficiency and system cost. Professional Animal Scientist, 27, 410-421. https://dx.doi.org/10.15232/S1080-7446(15)30513-1

Krause, A. D., Lardner, H. A., McKinnon, J. J., Hendrick, S., Larson, K., \& Damiran, D. (2013). Comparison of grazing oat and pea crop residue versus feeding grass-legume hay on beef-cow performance, reproductive efficiency, and system cost. Professional Animal Scientist, 29, 535-545. https://doi.org/10.15232/S1080-7446(15)30275-8

Kumar, R., Lardner, H. A., Christensen, D. A., McKinnon, J. J., Damiran, D., \& Larson, K. (2012). Comparison of alternative backgrounding systems on beef calf performance, feedlot finishing performance, carcass traits and system cost of gain. Professional Animal Scientist, 28, 541-551.

http://dx.doi.org/10.15232/S1080-7446(15)30403-4

Lardner, H. A. (2002). Comparison of grazing corn varieties. Fact sheet. No. 2002-02. Lanigan, Saskatchewan, Canada: Western Beef Development Centre. Saskatoon, Canada. http://www.wbdc.sk.ca/pdfs/fact_sheets/2002/comparison_of_grazing_corn_varieties.pdf

Lardner, H. A., Larson K., \& Pearce, L. (2012). Winter grazing beef cows with standing corn. Fact sheet No. 2012-03. Lanigan, Saskatchewan, Canada: Western Beef Development Centre. Saskatoon, Canada. http://www.wbdc.sk.ca/pdfs/fact_sheets/2012/2012.03_WBDC_winter_grazing_beef_cows_with_standing_ corn.pdf

Lassiter, C. A., Huffman, C. F., Dexter, S. T., \& Duncan, C. W. (1958). Corn versus oat silage as a roughage for dairy cattle. Journal of Dairy Science, 41, 1282-1285. https://doi.org/10.3168/jds.S0022-0302(58)91085-3

Lauer, J. G., Coors, J. G., \& Flannery, P. J. (2001). Forage yield and quality of corn cultivars developed in different eras. Crop Science, 41, 1449-1455. https://doi.org/10.2135/cropsci2001.4151449x

May, W. E., Klein, L. H., Lafond, G. P., McConnell, J. T., \& Phelps, S. M. (2007). The suitability of cool- and warm-season annual cereal species for winter grazing in Saskatchewan. Canadian Journal of Plant Science, 87, 739-752. https://www.nrcresearchpress.com/doi/pdf/10.4141/P06-026

McCartney, D., Fraser, J., \& Ohama, A. (2008). Annual cool season crops for grazing by beef cattle. A Canadian review. Canadian Journal of Animal Science, 88, 517-533. https://doi.org/10.4141/CJAS08052

McCartney, D., Fraser, J., \& Ohama, A. (2009). Potential of warm-season annual forages and brassica crops for grazing: A canadian review. Canadian Journal of Animal Science. 89, 431-440. https://doi.org/10.4141/CJAS09002

NRC. 2000. Nutrient requirements of beef cattle. 7th rev. ed. National Academy Press, Washington, DC.

NRC. 2001. Nutrient requirements of dairy cattle. 7th rev. ed. National Academy Press, Washington, DC.

Perkins, D. N., Alward, S. S., Davis, B. A., Gallien, O. J., Labelle, J. A. G., \& Monette, B. (1986). Soil landscapes of Canada: Alberta. Land Resource Research Centre, Research Branch, Agriculture Canada, Ottawa.

SAS Institute. (2003). SAS/STAT User’s Guide, Version 8.2. SAS Institute, Inc. p. 707. Cary, NC, USA:

Saskatchewan Ministry of Agriculture [SMA]. 2010. Saskatchewan accumulated corn heat units average CHUs 
for silage production.

http://irrigationsaskatchewan.com/icdc/wp-content/uploads/2014/11/CHU_average.pdf. Accessed 18 April 2016.

Saskatchewan Soil Survey. (1992). The soils of Prairie Rose rural municipality No. 309, Saskatchewan. Saskatchewan Institute of Pedology. University of Saskatchewan., Saskatoon, Canada.

Saxton, A. M. (1998). A macro for converting mean separation output to letter groupings in Proc. Mixed Model. Pages 1243-1246. In: Proceedings of 23rd SAS Users Group Int., Cary, NC.

Saskatchewan Minstry of Agriculture (2008). Annual crops for greenfeed and grazing. [online]. Available: http://www.agriculture.gov.sk.ca/Default.aspx?DN=b45a5f86-4eaf-41eb-a731-4a7bb90c646d.

Steel, R. G. D., Torrie, J. H., \& Dickey, D. A. (1997). Principles and procedures of statistics. A biometric approach. McGraw-Hill Co., Inc. 3rd Ed. New York, NY.

Taylor, C. C., \& Allen, M. S. (2005). Corn grain endosperm type and brown midrib 3 corn silage: Ruminal fermentation and $\mathrm{N}$ partitioning in lactating cows. Journal of Dairy Science, 88, 1434-1442. https://doi.org/10.3168/jds.S0022-0302(05)72811-3

Van De Kerckhove, A. Y., Lardner, H. A., Walburger, K., McKinnon, J. J., \& Yu, P. (2011). Effects of supplementing spring-calving beef cows grazing barley crop residue with a wheat-corn blend dried distillers grains with solubles on animal performance and estimated dry matter intake. Professional Animal Scientist, 27, 219-227. https://dx.doi.org/10.15232/S1080-7446(15)30477-0.

Van Soest, P. J., Robertson, J. B., \& Lewis, B. A. (1991). Symposium: Carbohydrate methodology, metabolism, and nutritional implications in dairy cattle. Journal of Dairy Science, 74, 3583-3597. https://doi.org/10.3168/jds.S0022-0302(91)78551-2

Weiss, W. P., Conrad, H. R., \& Pierre, N. R. St. (1992). A theoretically-based model for predicting total digestible nutrient values of forages and concentrates. Animal Feed Science and Technology, 39, 95-110. http://dx.doi.org/10.1016/0377-8401(92)90034-4

Yurchuk, T. \& Okine, E. (2004). Agri-facts: Beef Ration Rules of Thumb. Agdex 420/52-4. http://www1.agric.gov.ab.ca/\$department/deptdocs.nsf/all/agdex9146/\$file/420_52-4.pdf?OpenElement. Accessed April 2016. Alberta Agriculture Food and Rural Development.

\section{Copyrights}

Copyright for this article is retained by the author(s), with first publication rights granted to the journal.

This is an open-access article distributed under the terms and conditions of the Creative Commons Attribution license (http://creativecommons.org/licenses/by/3.0/). 